\title{
PHYSICAL AND CHEMICAL CHARACTERISTIC OF YOUNG COCONUT LEAVES (Cocos nucifera L.) AS TRADITIONAL PACKAGING
}

\author{
Uswatun Hasanah ${ }^{1)^{*}}$, Edlina Putri Sukma Dewi ${ }^{1)}$, Umar Santoso ${ }^{1)}$, Supriyadi ${ }^{1)}$
}

\author{
1) Department of Food and Agricultural Technology, Faculty of Agricultural Technology \\ Universitas Gadjah Mada, Jl. Flora No. 1 Bulaksumur, Yogyakarta, 55281 \\ ${ }^{*}$ Correspondence Email: myuswatunhasanah@gmail.com
}

\begin{abstract}
Traditional food is usually packed with natural packaging materials such as young coconut leaves (janur), but a little scientific information is available related to the packaging material. This study aimed to examine the physical and chemical characteristics of fresh and steamed janur $\left(30\right.$ minutes steaming at $\left.100^{\circ} \mathrm{C}\right)$. The physical and chemical properties of janur were expected to be the basis for the development of janur as an environmentally friendly packaging material. The results showed that fresh and steamed janur color was greenish-yellow and brownish-yellow. The fresh and steamed janur had a tensile strength 19.19 MPa and $30.62 \mathrm{MPa}$; water content $73.54 \%$ and $69.57 \%$; and fat content $1.85 \%$ and $0.54 \%$, respectively. After steaming, the microstructure of the cells became finer and irregular. The dominant fatty acid in fresh janur and steamed janur was palmitic acid $(24.27 \%)$, and palmitoleic acid (38.56\%), respectively. The treatment of steaming of janur influenced the physical and chemical characteristics of packaging materials.
\end{abstract}

Keywords: janur, traditional packaging, physical and chemical characteristics

\section{INTRODUCTION}

Indonesia is rich in cultural diversity in each region. It causes various kinds of traditional foods related to ingredients, processing, and packaging (Sabana, 2007). Mostly used packaging materials for traditional foods are leaves, such as janur, kelobot, banana leaf, teak leaf, etc.

Leaves are known as eco-friendly food packaging material. It also maintains the diversity of leaves that have grown up in tropical regions (Casey, 2015). The development of technology and lifestyle causes the replacement of traditional packaging with modern ones, like plastics. However, modern packaging materials are not eco-friendly, so it is necessary to maintain unique traditional packaging to become a natural packaging suitable for use (Noviadji, 2014).

To the best of our knowledge, research on the packaging of traditional food is limited. Some of the leaves have not provided information about their characters as packaging materials, for example, janur. In this research, we will explore and determine the suitability of janur as a food packaging material. The process of steaming janur initiates a positive interaction of the natural components of the leaves with the product on the flavor and quality of the product. Things that support the selection of leaves as packaging materials are physical and chemical characteristics.

Physical characteristics (color, tensile and tear strength, and cell microstructure) and chemical characteristics (moisture content, fat content, and fatty acids profile) of janur are expected to be the basis for the development of leaves as eco-friendly packaging materials.

\section{MATERIALS AND METHODS}

\section{Materials}

The raw material used in this study included young coconut leaves picked from the Temon area, Kulon Progo. The yellowish-green leaves taken from the base of the tree were used in this study. There were two treatments for the janur, fresh and steamed $\left(100^{\circ} \mathrm{C}\right.$ for 30 minutes $)$.

Material for analysis consisted of Petroleum Ether (PE), standard mix FAME, Sodium Hydroxide $(\mathrm{NaOH})$ p.a in methanol, Boron Tetrafluoride $\left(\mathrm{BF}_{3}\right) 16 \%$, Saturated Sodium Chloride $(\mathrm{NaCl})$, Hexane $\left(\mathrm{C}_{6} \mathrm{H}_{14}\right)$ and Sodium Sulfate $\left(\mathrm{Na}_{2} \mathrm{SO}_{4}\right)$ anhydrous.

\section{Methods}

\section{Preparation}

Janur was cleaned first from the dirt by wiping it, then released from the midrib and separated from the middle stem (stick). Some of the janur were steamed since this treatment is commonly practiced in traditional food preparation. $500 \mathrm{~g}$ of janur was tied and put into a container containing boiling water steamed at $\pm 100^{\circ} \mathrm{C}$ for 30 minutes (based on habits in the community) until it turned yellowish. After steaming, the water vapor was removed first by being spread on a tray. The leaves were dried air at room temperature ( 3 days for steamed leaves and 7 days for fresh leaves until the water content is $<15 \%$ ) (Hossain et al., 2011). Dried leaves were cut and reduced in size using a grinder then sifted through 30 mesh.

\section{Analysis of Fresh and Steamed Janur}

Analysis of physical characteristics included color (Chromameter CR-400 merk Konica Minolta), tensile strength (Universal Testing Machine (UTM) merk ZWICK/Z05), tear strength (Universal Testing Machine merk ZWICK/Roell Z020), and Cell microstructure using SEM (Scanning Electron Microscopy). Analysis of Water and Fat content were performed using methods described in AOAC (2005).

The color of the leaf was determined by the three color stimuli, namely Lightness $\left(\mathrm{L}^{*}\right)$, appearance $\left(\mathrm{a}^{*}\right)$, and 
blueness $\left(b^{*}\right)$. The leaves were placed in the available container, then analyzed. The analysis was carried out on three different leaves, with each leaf being carried out in three parts, namely the tip of the leaf, the middle of the leaf, and the base of the leaf. In color measurement, the coordinates showed the degrees of brightness (L), degrees of red $(+\mathrm{a} *)$ or green $(-\mathrm{a} *)$, and degrees of yellow $(+\mathrm{b} *)$ or degrees of blue $(-\mathrm{b} *)$, respectively.

\section{Fatty acid profile}

The analysis was started with fat extraction by soxhlet based on AOAC (2005) using Petroleum Ether solvents until the fat was obtained are then evaporated with nitrogen gas. The fat obtained was weighed as much as $0.3002 \mathrm{~g}$ (from $2 \mathrm{~g}$ of leaf powder) in the test tube then $1 \mathrm{~mL}$ of sodium hydroxide $(\mathrm{NaOH})$ p.a in methanol $\left(\mathrm{CH}_{3} \mathrm{OH}\right)$ was added. The samples was then heated in a water bath for 20 minutes, followed by adding $2 \mathrm{ml}$ of boron tetrafluoride $\left(\mathrm{BF}_{3}\right) 16 \%$ to the test tube. Subsequently, the samples were reheated for 20 minutes. Afterward, the samples were cooled and added with $2 \mathrm{~mL}$ of saturated sodium chloride $(\mathrm{NaCl})$ and $1 \mathrm{~mL}$ hexane $\left(\mathrm{C}_{6} \mathrm{H}_{14}\right)$. The solution was shaken well then the top layer or hexane $\left(\mathrm{C}_{6} \mathrm{H}_{14}\right)$ was separated by pipette into a test tube containing $0.1 \mathrm{~g}$ sodium sulfate $\left(\mathrm{Na}_{2} \mathrm{SO}_{4}\right)$ anhydrous. Leave until it dissolves. After water removal, a total of $1.5 \mathrm{~mL}$ of sample was transferred to the vial to be injected to the GC. Fat content analysis was carried out using the Agilent GC-FID, DB-23 column $30 \mathrm{~m}$ long, 0.25 $\mathrm{mm}$ inner diameter and $0.25 \mu \mathrm{m}$ particle diameter, nitrogen carrier gas. The methylated sample was inserted into the vial then placed in the GC tray. The standard volume of mix methyl ester (FAME) and the injected sample was 1 $\mu \mathrm{L}$. The temperature of the injector was held at $100{ }^{\circ} \mathrm{C}$ for 5 minutes, the oven temperature was increased to $275^{\circ} \mathrm{C}$ at a rate of $4{ }^{\circ} \mathrm{C} /$ minute held for 10 minutes, the oven heating temperature system used was isothermal at the oven's initial temperature $290{ }^{\circ} \mathrm{C}$ held for 15 minutes. The results were read with the FID detector at $285{ }^{\circ} \mathrm{C}$. The retention time and peak area of each compound were then compared to the standard mix methyl ester (FAME) for the qualitative and quantitative analysis.

\section{RESULT AND DISCUSSION}

\section{Physical Characteristics}

\section{Color}

The results showed that fresh janur had a rather dark green color, Whereas steamed janur had a yellow color. Steaming caused color changes in janur, there were faded green and increasing yellow. The fading of the green leaf was thought to be due to the degradation of chlorophyll a and b. High temperatures during steaming can cause the replacement of magnesium in chlorophyll by hydrogen, thereby converting green chlorophyll into brown peophytin compounds so that the total chlorophyll of leaf extract is lower (Shonte and De Kock, 2017).

Table 1. showed that the lower $\mathrm{L}$ value indicates a darker color, while the higher L value indicates the brighter yellow. The color of fresh janur was greenish-yellow and brownish- yellow for steamed janur. A minus value indicates a darker green color and the higher $\mathrm{b}$ value indicates a brighter yellow color (Song and Banyo, 2011).

Table 1. Color of fresh and steamed janur

\begin{tabular}{cccc}
\hline \multirow{2}{*}{ Treatment } & \multicolumn{3}{c}{ Parameter } \\
\cline { 2 - 4 } & $\mathbf{L}$ & $\mathbf{a}$ & $\mathbf{b}$ \\
\hline Fresh Janur & $68.70^{\mathrm{a}}$ & $-0.16^{\mathrm{a}}$ & $9.92^{\mathrm{a}}$ \\
Steamed Janur & $63.07^{\mathrm{b}}$ & $0.35^{\mathrm{b}}$ & $21.87^{\mathrm{b}}$ \\
\hline
\end{tabular}

\section{Tensile Strength and Tear Strength}

The result of tensile strength and tear strength can be found in Table 2. Tensile strength of fresh and steamed janur was $9.19 \pm 0.03 \mathrm{MPa}$ and $30.62 \pm 0.01 \mathrm{Mpa}$, respectively. Steaming treatment on the sample caused a stronger value of tensile strength because the water content was also reduced (Badar, 2006). The value of the tear strength of fresh janur was 1.61 $\pm 0.03 \mathrm{~N} / \mathrm{mm}$, then after the steaming process, the value of tear strength increased to $1.66 \pm 0.15 \mathrm{~N} / \mathrm{mm}$. However, the statistical analysis results showed that the value of the tear strength of fresh and steamed janur was not significantly different at $\alpha=0.05$. Based on the tear strength test results, the value of tear strength after steaming was higher than that of fresh leaves. The tear strength value was also related to the water content in the leaves and the tensile strength, where the high water content results in a large number of hydrogen bonds between water molecules, causing a small tear strength. In steamed janur, the hydrogen bonds between small water molecules were strong, so there was only a powerful hydrogen bond between cellulose (Badar, 2006). Janur consisted of leaf fibers, which were relatively smooth and even. The presence of fiber is thought to affect the strength of the tearing palm.

Table 2. Tensile Strength and Strong Tear of fresh and steamed janur

\begin{tabular}{ccc}
\hline \multirow{2}{*}{ Treatment } & \multicolumn{2}{c}{ Parameter } \\
\cline { 2 - 3 } & $\begin{array}{c}\text { Tensile Strength } \\
(\mathbf{M P a})\end{array}$ & $\begin{array}{c}\text { Tear Strength } \\
\mathbf{( N / m m )}\end{array}$ \\
\hline Fresh Janur & $19.19 \pm 0.83^{\mathrm{a}}$ & $1.61 \pm 0.03^{\mathrm{a}}$ \\
Steamed Janur & $30.62 \pm 0.61^{\mathrm{a}}$ & $1.66 \pm 0.15^{\mathrm{a}}$ \\
\hline
\end{tabular}

\section{Cell microstructure}

Giving heat in the steaming process can break down the tissue so that the cell wall of the stem becomes open while the plants need membrane stability during stress conditions (Blum and Ebercon, 1981). There was a positive impact from the blanching process or preheating on antioxidant activity, which may be related to the destruction of cell walls and subcellular parts in vegetables which resulted in an easier release of antioxidant components. The existence of heat treatment in the form of steaming on leaf apart from being a packaging material was expected to have more value on the nutritional content of the product (Mazzeo et al., 2011).

Figure 1. showed that in fresh janur, the tissue was still tight, the fibers looked more orderly and sturdy. After steaming changes occurred to the fibers that appear to be wider, finer, and irregular. 


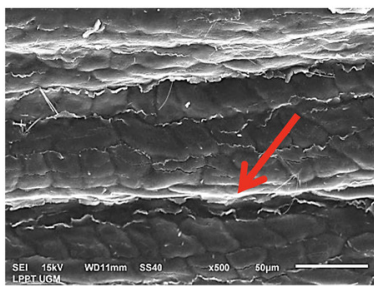

A

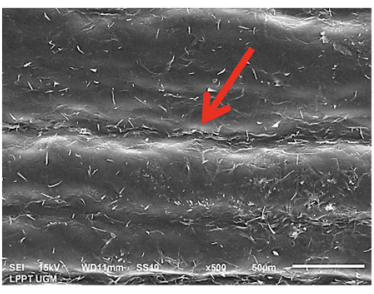

B
Figure 1. The microscopic cell of fresh (A) and steamed janur (B) at zoom 500x.

\section{Chemical Characteristics}

\section{Water and fat content}

The result of moisture and fat content can be found in Table 3. The moisture content of the fresh and steamed janur was significantly different. The moisture content of fresh janur was $73.54 \pm 0.30 \%$, and steamed janur was $69.57 \pm 0.86 \%$. Heat processing like steaming and drying caused the evaporation of water in the sample. This evaporation caused a decrease in water content (Thamrin and Prayitno, 2008).

The fat content of fresh janur $(1.85 \pm 0.09 \%)$ and steamed janur $(1.06 \pm 0.11 \%)$ was also significantly different. Fat content decreased after the steaming process. The high temperature that was used in this process caused damage to lipids (Palupi et al., 2007).

Table 3. water and fat content of fresh and steamed janur

\begin{tabular}{ccc}
\hline \multirow{2}{*}{ Treatment } & \multicolumn{2}{c}{ Parameter } \\
\cline { 2 - 3 } & Water content & Fat content \\
\hline Fresh Janur & $73.54 \pm 0.30^{\mathrm{a}}$ & $1.85 \pm 0.09^{\mathrm{a}}$ \\
Steamed Janur & $69.57 \pm 0.86^{\mathrm{b}}$ & $1.06 \pm 0.11^{\mathrm{b}}$ \\
\hline
\end{tabular}

\section{Fatty acid profile}

Table 4. Fatty acid profile of fresh and steamed janur

\begin{tabular}{|c|c|c|c|}
\hline \multirow{2}{*}{ No. } & \multirow{2}{*}{ Fatty acid } & \multicolumn{2}{|c|}{ Area (\%) } \\
\hline & & Fresh Janur & Steamed Janur \\
\hline 1 & Palmitic acid & 25.43 & - \\
\hline 2 & Lignoceric acid & 28.36 & - \\
\hline 3 & Stearic acid & 2.89 & - \\
\hline 4 & Palmitoleic acid & - & 37.96 \\
\hline 5 & Elaidic acid & 18.84 & 13.57 \\
\hline 6 & Oleic acid & - & 12.87 \\
\hline 7 & Linolelaidic acid & 17.04 & 20.94 \\
\hline \multirow[t]{2}{*}{8} & $\alpha$-Linolenic acid & 7.45 & 14.65 \\
\hline & Total & $100 \%$ & $100 \%$ \\
\hline
\end{tabular}

Based on the results of testing the fatty acid profile presented in Table 4., it was found that the dominant fatty acid in janur was unsaturated fatty acids. Each of the fresh and steamed ingredients contained $56.68 \%$ and $100 \%$ unsaturated fatty acids, in other words, the steaming process changed the fatty acid composition of the janur to become unsaturated. The changes in unsaturated fatty acid residues in cellular membranes determined the nature of membranes against low and high-temperature tolerances and pathogenic fungi (Wahid et al., 2007). The occurrence of a very significant change in the amount of palmitoleic acid and the absence of palmitic acid in steamed leaves was thought to be due to the activity of the fatty acid desaturase enzyme, an enzyme that removes 2 hydrogen atoms from single chain fatty acids to double bonds carbon form. Palmitoleic acid is the biosynthesis of palmitic acid due to the activity of the delta-9 desaturase enzyme (Arregui et al., 2012). It showed that steamed janur was easier to oxidize and was more radical than fresh janur. The steaming process caused the entire fatty acid composition of the janur to become unsaturated. This result was a new finding so there is a possibility that it could affect the quality of packaging materials.

\section{CONCLUSION}

From this research, it can be seen that the steaming treatment on janur had effects on the physical and chemical characteristics of traditional packaging materials. The color of fresh and steamed janur was greenish-yellow and brownish-yellow, tensile strength $19.19 \mathrm{MPa}$ and 30.62 MPa, water content $73.54 \%$ and $69.57 \%$; fat content $1.85 \%$ and $0.54 \%$, respectively. The microstructure of the cell after steaming changes became finer and irregular. The dominant fatty acid in fresh janur was palmitic acid (24.27\%), in steamed janur was palmitoleic acid (38.56\%).

\section{REFERENCES}

AOAC. 2005. Official method of Analysis of the Association of Analytical Chemist. Benyamin Franklin Station. Washington D.C.

Arregui, M., Buijsse, B., Stefan, N., Corella, D., Fisher, E., Di Giuseppe, R., Coltell, O., Knüppel, S., Aleksandrova, K., Joost, H.G. and Boeing, H. 2012. Heterogeneity of the Stearoyl-CoA desaturase-1 (SCD1) gene and metabolic risk factors in the EPIC-Potsdam study. PloS one.7(11): p.e48338.

Badar, A.A. 2006. Karakterisasi Sifat Fisiko Kimia Dan Mekanik 'Daun Patat Daun (Phrynium Capitatum) Sebagai Bahan Kemasan. Skripsi. Institut Pertanian Bogor.

Blum, A. and Ebercon, A. 1981. Cell membrane stability as a measure of drought and heat tolerance in wheat 1. Crop Science. 21(1): pp.43-47.

Casey, N. 2015. Plant leaves in food preparation and packaging. UTAR Agriculture Science Journal (UASJ). 1(4): pp.34-39.

Hossain, M.A. and Shah, M.D. 2015. A study on the total phenols content and antioxidant activity of essential oil and different solvent extracts of endemic plant Merremia borneensis. Arabian Journal of Chemistry. 8(1): pp.66-71.

Mazzeo, T., N'Dri, D., Chiavaro, E. Visconti, A., Fogliano, V. and Pellegrini, N., 2011. Effect of two cooking procedures on phytochemical compounds, total antioxidant capacity and colour of selected frozen vegetables. Food Chemistry. 128(3): pp.627-633.

Noviadji, B.R. 2014. Desain kemasan tradisional dalam konteks kekinian. Jurnal Fakultas Desain. 1(1): pp.10-21.

Palupi, N.S., Zakaria, F.R. and Prangdimurti, E. 2007. Pengaruh pengolahan terhadap nilai gizi pangan. Modul e-Learning ENBP, Departemen Ilmu \& Teknologi Pangan-Fateta-IPB. pp.1-14.

Sabana, S. 2007. Nilai Estetis Pada Kemasan Makanan Tradisional Yogyakarta. Jurnal Visual Art. 1(1): pp.10-25.

Shonte, T.T. and De Kock, H.L. 2017. Descriptive sensory evaluation of cooked stinging nettle (Urtica dioica L.) leaves and leaf infusions: Effect of using fresh or oven-dried leaves. South African Journal of Botany. 110: pp.167-176.

Song, A.N. and Banyo, Y. 2011. Konsentrasi klorofil daun sebagai indikator kekurangan air pada tanaman. Jurnal ilmiah sains. 11(2): pp.166-173.

Thamrin and Prayitno L. 2008. Pengaruh lama perebusan dan perendaman terhadap kadar air dan tingkat kelunakan kolang-kaling. In Prosiding Seminar Nasional Sains dan Teknologi. 8: pp.44-49.

Wahid, A., Gelani, S., Ashraf, M. and Foolad, M.R. 2007. Heat tolerance 
in plants: An overview. Environmental and experimental botany.

61(3): pp.199-223. 